University for Business and Technology in Kosovo

UBT Knowledge Center

Oct 27th, 4:45 PM - 6:15 PM

\title{
Performance Measurement System Based on Process Approach
}

\author{
Ernad Kahrović \\ State University of Novi Pazar, ekahrovic@np.ac.rs
}

Follow this and additional works at: https://knowledgecenter.ubt-uni.net/conference

Part of the Business Commons

\section{Recommended Citation}

Kahrović, Ernad, "Performance Measurement System Based on Process Approach" (2017). UBT International Conference. 252.

https://knowledgecenter.ubt-uni.net/conference/2017/all-events/252

This Event is brought to you for free and open access by the Publication and Journals at UBT Knowledge Center. It has been accepted for inclusion in UBT International Conference by an authorized administrator of UBT Knowledge Center. For more information, please contact knowledge.center@ubt-uni.net. 


\title{
Performance Measurement System Based on Process Approach
}

\author{
Ernad Kahrović ${ }^{1}$ \\ ${ }^{1}$ State University of Novi Pazar, Department of Economics Sciences \\ 36300 Novi Pazar, Vuka Karadžića bb, Republic of Serbia \\ ekahrovic@np.ac.rs
}

\begin{abstract}
This paper addresses issues met when designing, implementing, using and continuously updating performance measurement system based on process approach. Process approach in managing is necessary since it provides a new perspective to the company's management in terms of identifying problematic, inefficient processes and activities that have negative impact on the overall efficiency and competitive position of the company. Such business management which includes adoption and implementation of the process approach requires consideration of the issues related to performance measurement system based on business process approach as a key control and management instrument. Therefore, the aim of this paper is to shed light on the key moments in the design and implementation of the performance measurement systems in a process-oriented company. In order to look at the above mentioned issues, the attention is given to the important moments and phases in developing a system to measure the performance characteristics of the business processes in a process-oriented company.
\end{abstract}

Keywords: business processes, measurement system, processes performances

\section{Introduction}

In the knowledge economy era, the key resources for gaining a sustainable competitive advantage are of immaterial, intangible, or intellectual. In modern business environment, mission and strategic goals of a company cannot be realized without adequate creation, combination and application of knowledge and other intangible resources. Furthermore, the importance of intellectual capital for the successful performance of the company and the increase of its market value is generally acknowledged. Intellectual capital, in the information age, is the key factor in maintaining and improving competitive advantage (Krstić, 2009). Trends related to creating value for the shareholders and maintaining competitive position are changing. Namely, competitive struggle between market rivals in the knowledge economy differs significantly in several aspects from business operations and market competition between companies in the industrial age.

First, the successful management in the global business environment, among other things, implies networking of an enterprise with its customers, employees, suppliers, strategic partners and the community. Second, one of the vital market factors that distinguish one enterprise from other market participants is the quality of services provided to consumers. Third, the key to business success of each enterprise in the "new economy" is the capability to predict the market discontinuities and respond to new trends and changes in technology in a particular industry. Therefore, the requirements to make changes in the manner in which one company competes with other firms, to constantly innovate, to increase flexibility and improve the skills and competencies within this company are always present. Fourth, the appropriate application of 
modern technologies can significantly contribute to improving the competitiveness of enterprises. Fifth, the change in orientation from the vertical orientation and functionally oriented management to the process oriented one, i.e. to the horizontal organization and process-oriented management is also relevant. This orientation determines the management of a series of interrelated business processes, which actually makes the particular business process the key management issue.

\section{Characteristics of process approach in modern enterprise management}

Dynamic competitive conditions gradually reduce the significance of the classical, functional models of organizational structuring, because they are based on a vertical, hierarchical organization that has shown a number of limitations that reduce the effectiveness of both organizational and business units. Therefore, companies need to eliminate deficiencies of the functional organization and vertically oriented management (Becker, Kugeler, Rosemann, 2003, p. 2)

Due to the numerous benefits regarding the efficiency and competitiveness, the dominant trend in many companies in the last two decades is that of the transformation to the process orientation and process-oriented management. The main characteristic of the process-oriented management is a process as an object of control, and its main goal is the improvement of the business processes performances (Sekulic, Krstic, 2005). Process-oriented company is set up by transforming traditional (functional) structure to the new process structure, i.e. the organizational units responsible for particular functions are based on business processes rather than business functions (departments). This means that jobs are not grouped according to similarities in functional units, as is the case with a functional organizational design, but according to their connection with the specific process. A company with a hierarchical system of functional units, through transformation towards process orientation, becomes "flatter", with fewer levels of management, while autonomous process teams perform particular activities within business processes from their beginning to their end (Krstić, Jovanović, Kahrović, 2012).

Process orientation has introduced innovations to the business performance management system of a modern enterprise. In addition to management at the enterprise, business unit or organizational unit (functional department) level, yet another level of performance management is created - that of process performance management. Processes performance management can be determined as the result, effect or output of a business process or activity, which can be expressed through a quantitative or qualitative value. If we accept that a process represents a complex object of control, which consists of the activities, operations and tasks, then a conceptual framework of business process performance incorporates the following: the performance of the activities of a business process, the performance of operations included in the activities of a business process and performance related to execution of tasks within the operations (activities) of a business process. Therefore, it is necessary to plan, measure, analyze and improve the performance of business processes, as well as the activities that constitute them. Process approach to management makes it possible to better identify the causes and factors of enterprise functioning in relation to the classical concept of enterprise management, i.e. the functional organizational design. The process approach is a tool that allows a more profound, more precise, new look at the essence of the company's operations and the causes and factors of its business performance. 


\section{Determinants and phases in performance measurement system}

The key issue of effective business process performance measurement is the development of an adequate performance measurement system in a process-oriented enterprise. Such system should support the implementation of the existing strategies and plans for business processes improvement (Kueng, 1999, p. 154). At the same time, information on the measurements represent the basis for the analysis of the strategy implementation, as well as for taking corrective actions in terms of improving the performance of individual business processes (Sekulić, Krstić, 2005; Anđelković-Pešić, Milić-Janković, 2005).

It is proposed here that development of performance measurement system based on process approach can be divided into four main stages: (1) Performance measurement system design, i.e. selection of business process performance indicators; (2) Preparation for the implementation of business process performance measurement system; (3) Implementation of the business process performance measurement system; (4) Finding opportunities for improving the business processes performance measurement system.

\section{Performance measurement system design}

A company that chooses to implement process-orientation management must also work on changing the performance measurement system that used to be applied. In the phase of designing performance measurement system, i.e. selection of performance indicators for each business processes, it is necessary to make a decision about what will be measured and how it will be measured. Strategic approach is considered as the most suitable one for the selection of business processes performance measures, since this approach is based on the strategy and programmes for the business process improvement, as well as the identified business process success factors (Neely, Bourne, Kennerley, 2000).

Elaboration of such concept referring to the selection of the process performance measures based on the business process improvement strategy and programmes and identified business process success factors, involves determining the so-called elements of the business process measurement definition. The elements included in the definition of each selected criteria of a business process performance measurement system in a particular company (Kahrović, 2013).

It is necessary to check the appropriateness of the defined business processes indicators, as well as the criteria for their selection. The selection is usually performed from a large number of possible indicators, which the economic science and successful business practice recommend for the tracking and controlling of business processes. When one wants to measure the performance features of the business process, it is necessary to understand and verify the elements included in the definition of the indicator, which are listed in Table 1. 
Table 1. Elements of the definition of the business process performance indicators (Krstic, 2012, p. 165)

\begin{tabular}{|c|c|c|c|c|c|c|c|c|c|c|}
\hline 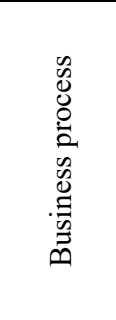 & 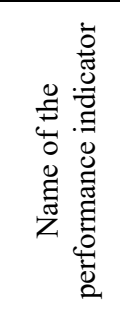 & 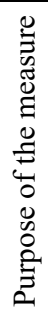 & 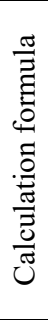 & 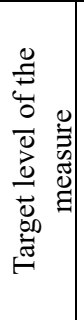 & 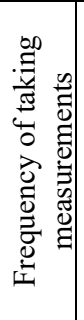 & 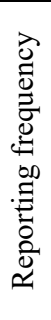 & 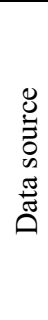 & 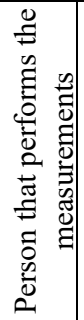 & 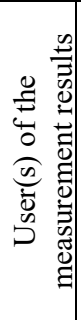 & 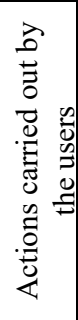 \\
\hline $\begin{array}{l}\text { Business } \\
\text { process } \\
1\end{array}$ & $\begin{array}{l}\text { Indicator } \\
\mathrm{A} \\
\text { Indicator } \\
\mathrm{B} \\
\text { Indicator } \\
\mathrm{C}\end{array}$ & & & & & & & & & \\
\hline $\begin{array}{l}\text { Business } \\
\text { process } \\
2\end{array}$ & $\begin{array}{l}\text { Indicator } \\
\text { A } \\
\text { Indicator } \\
\text { B } \\
\text {. . . }\end{array}$ & & & & & & & & & \\
\hline
\end{tabular}

Namely, for each selected business process performance indicator the following should be defined and checked: 1 . The name of the performance indicator (most measures are specially determined for the control and tracking of a process, therefore they do not have a conventional name, which is the case with traditional financial performance indicators that have been used in financial analysis); 2 . The purpose of the business process measurement (this should give an answer to the question what is measured by a particular performance indicator and why is it important to measure particular process); 3. A method of calculating the measure (calculation formula, calculation method, the methodology applied in the process of data collection); 4. A target level of particular performance measure (a planned level of a particular performance which is to be achieved in the future); 5. Frequency of taking the measurements based on the certain business process performance measurement (daily, weekly, monthly, etc.); 6. Reporting frequency, concerning the responsible persons and other persons responsible for the implementation of activities within a single process); 7. Information source and the manner of collecting information for calculating the value of a certain process performance measure; 8 . The person who performs the measurement); 9. Users of information on completed process performance measurement, as well as actions carried out by these users (process managers and others) based on information obtained by the measurements taken.

\section{Preparation for the implementation of measurement system}

Prior to implementation of a determined business process performance measurement system, due to the previously described selection of business process performance indicators, it is necessary to make appropriate preparations. Preparation involves screening for the existence of potentially redundant process performance indicators in a selected set (system) of business process performance indicators. This verification procedure for indicators should be carried out on the basis of the testing validity and reliability of the selected criteria. Validity is related to the extent to which the measure successfully quantifies the selected feature. Reliability is related to the 
degree to which" technique" and measurement methodology reveals the actual process performance changes over time and does not introduce errors in measurement results. (Krstić, Sekulić, 2009, p. 90).

\section{Implementation of the business process performance measurement system}

The actual implementation of the established business process performance measurement system in an enterprise involves daily use of certain indicators used for the control and information purposes on the achieved process performance (Martin, 2008, p. 34). Therefore, it is necessary to initiate appropriate actions to improve the business process performances based on the results of the measurements. If the implementation of actions for business process improvement does not take place, the measurement process as a part of the business process management will not contribute to the quality of the process and will only produce costs and expenses. The obtained information is first analyzed and consolidated in order to formulate and produce conclusions based on the performed analysis. Persons responsible for individual business processes should produce the assessment of the level of achieved performance, as well as determine what needs to be changed (shortened time span for activity realization, elimination of the non-value adding activities, improvement of the process output quality, etc.) based on the identified causes and effects. Before the obtained information is translated into actions, it should be checked for the following: potential errors in data collection, measurement errors, as well as the possible manipulation of certain data (Krstić, Sekulić, 2013, p. 91).

\section{Opportunities for improving the measurement system}

On the other hand, the continuous improvement of business processes performance measurement systems is necessary in order to keep the process useful and relevant for management (Krstić, Sekulić, 2013, p. 93). For this reason it is important to keep reviewing the process. Certain measures in the business process performance measurement systems can at one point of time become irrelevant for management, namely become redundant. Some indicators are introduced into the measurement system only as temporary indicators in order to control the problematic activities of a process at that particular time, and it also can happen that due to uncritical assessment of these temporary indicators they remain in a measurement system for some period of time. Redundant measures in the measurement system cause greater utilization of resources (increasing the costs of collecting information necessary for measurement) and loss of productive time of the persons performing the measurements and performance control. In addition, it may happen that one problematic business process or some area of its activity remain ambiguous due to the insufficient information, lack of indicators for monitoring the effectiveness of such activity. This means that any new indicators must be introduced into the measurement system which would identify specific problems in implementation of the activities and operations incorporated in a particular business process. Of course, it is not most appropriate to constantly introduce new indicators in business process performance measurement system, because it increases the complexity of the measurement system, incurs unwanted costs and distracts the attention of the process management by making them focus on too many performance indicators that should be observed and upon which they should make decisions on possible business process performance improvements. 


\section{Conclusion}

The developed performance measurement system has an important role in achieving a balance between the short-term results and long-term growth and development opportunities. It represents the basis for making good business decisions about the growth and development opportunities, the manner of their realization and strategic guidance, as well as the operational decision-making and implementation of the adopted long-term strategies. Adequate and integrated business process performance measurement system will help in the process of translating strategic plans into short-term actions and operational objectives, where the realistic assessments and decisions are made in terms of the efficient utilization of resources based on the on real, comprehensive and accurate measurements and thanks to a quality set up and consistently implemented integrated measurement system, and which provide a realistic assessment on efficient use of resources. In addition, an integrated performance measurement system enables monitoring of the process of implementation strategies. In the process of strategy formulation, measurement has an important role since it provides critical information for the proper definition of initial assumptions. At the end of the strategic process, integrated measurement system and the information that it provides are relevant for the reformulation of the strategy. With this in mind, such measurement system represents an instrument used by the company's management in deciding about various business initiatives, programmes and projects, by whose implementation the strategy is being realized. Finally, a properly structured and equitable system of compensation has a quality integrated business process performance measurement system as its basis.

\section{References}

1. Anđelković-Pešić, M., Janković-Milić, V., Statistički instrumenti u funkciji unapređenja poslovnih procesa, Poslovna politika, maj, str. 38-41, (2005)

2. Becker, J., Kugeler, M., Rosemann M., Process Management - A Guide for the Design of Business Processes, Springer, Berlin (2003)

3. Kahrović, E., Design and implementation of business process performance measurement system, Facta Universitatis Series: Economics and Organization, Vol. 10, No. 3, 2013, pp. 283-299, (2013)

4. Krstić, B., Intelektualni kapital i konkurentnost preduzeća, Ekonomski fakultet, Niš, (2009)

5. Krstić, B., Jovanović, S., Kahrović, E., Process-oriented enterprise as a determinant of organization behavior in Contemporary Business Term, Actual Problems of Economics, No. 11 (137), pp. 369-379, (2012)

6. Krstić, B., Uloga strategijske kontrole u unapređenju poslovnih performansi, Ekonomski fakultet, Niš (2012)

7. Kueng, P., Building a Process Performance Measurement System: some early experiences, Journal of Scientific and Industrial Research, Vol. 58, No. 3-4, pp. 152-165, (1999)

8. Sekulić, V, Krstić, B., Upravljanje performansama preduzeća, Ekonomski fakultet, Niš, (2013)

9. Neely, A., Bourne, M., Kennerlay, M., Performance measurement system design: developing and testing a process-based approach, International Journal of Operations \& Production Management, Vol. 20, No. 10, pp. 1119-1145, (2000) 